\title{
ガラス併用溶融紡糸した銅繊維の加熱 における発熱について
}

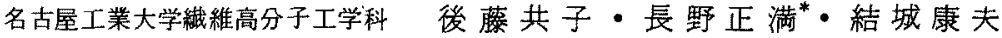 \\ 故小田隆・高井博和
}

\section{EXOTHERMIC BEHAVIOR ON HEATING OF COPPER FIBER MANUFACTURED BY THE METHOD OF GLASS CONJUGATED MELT SPINNING}

\author{
By Tomoko Goto, Masamitsu Nagano, Yasuo Yuki, \\ the late Takashi Oda and Hirokazu Takai \\ (Nagoya Institute of Technology, Department of Fiber and Polymer Technology, \\ Gokiso-cho, Showa-ku, Nagoya, Japan)
}

\begin{abstract}
The thermal analysis of copper fiber, which was manufactured by the method of glass conjugated melt spinning in changing the winding speed and cooling treatment and removed the glass in dissolving into alkali solution, have been studied in the temperature from $20^{\circ} \mathrm{C}$ to $450^{\circ} \mathrm{C}$.

The exothermic change of the heat capacity at $250^{\circ} \mathrm{C}-350^{\circ} \mathrm{C}$ was found in differential scanning calorimetry. The value of differential power output $(S J)$ and starting change temperature $\left(T_{t}\right)$ depended on the heating rate $(\phi) . \Delta J$ and $T_{t}$ were increased by increasing the heating rate. This change was considered as the release of stored energy in spinning. The relationship between the $\phi$ and $T_{t}$ was represented $\ln \left(\phi / T_{t}\right)=C-E / R T_{t}$, where $E$ is the apparent activation energy, $R$ the gas constant and $C$ constant.

Activation energy was obtained to be $14.0 \mathrm{Kcal} / \mathrm{mol}$ and gave reasonalbe agreement with that of self-diffusion of of copper.

Tensile strength decreased and elongation increased on heating at $370{ }^{\circ} \mathrm{C}$ for $5 \mathrm{~min}$.
\end{abstract}

(Received September 10, 1973)

\section{1. 緒言}

近年めざましい複台材料の発展，エレクトロニクスの

小型化による金属瀻維の必要性が増している。著者ら洼 現在工業的に多量生産方式の確立されている高分子の溶 融紡东法を利用して金属の溶虽紡米を行なった口。従来 瀻維科学においては材料として高分子を対象としてきた がそれに比較し化学的にも物理的にも簡単な構造から成 り古くから研究がなされている金属が高分子と同様な加 工処理を受けて織維状となった場合の諸物性は基䃈的な 問題として非常に重要なむのである。本研究はその一部 としてH.Wagnerのソ斬特許によるガラスの电系性を利 用して紡系した銅織維の室温から $450^{\circ} \mathrm{C}$ までの加熱によ

present address:Kagacho-1-18-1, Itabashi -Ku, Tokyo, Japan.

*東京家政大学 College of Tokyo Kasei 東京都 板橋区加賀町 1-18-1
る発熱側への熱容量の変化について検討した。

\section{2. 実験}

\section{1 实㩆試料}

主要部を図 1 に示す紡系装置により前報 ${ }^{1)}$ と同様に紡 糸した 2 系列の銅繊維を試料とした。すなるち直径 8 $\mathrm{mm} の$ パイレックス・ガラス管内に銓片約 $1 \mathrm{gr}$ を入れ， これを高周波誘導加熱溶融しその先端を他のガラスで溶 接しガラス管とともに引き出し巻取機で卷取る。使用し た高周波発振器は日本高周波株式会社製 $Y K-8-C$ 型誘 導加熱装瞋，周波数 $1 \mathrm{MHz}$ ，出力 $5 \mathrm{~kW}$ である。加熱コ イルは 2 巻きで内径約 $10 \mathrm{~mm}$ ののである。卷取装置と して日東紡株式会社製可变巻取型の特殊装店を使用した。 卷取速度 $137 \mathrm{~m} / \mathrm{min}$ で紡米口から $0 \mathrm{~cm} \sim 6 \mathrm{~cm}$ の各 位置で来隶を噴水し，冷却効果の異なる銅瀻維を作製し た。これを試料 1 とする。さらに米水で冷却はずに室温 $20^{\circ} \mathrm{C}$ で巻取速度を $48 \mathrm{~m} / \mathrm{min}$ から $137 \mathrm{~m} / \mathrm{min}$ まで变 


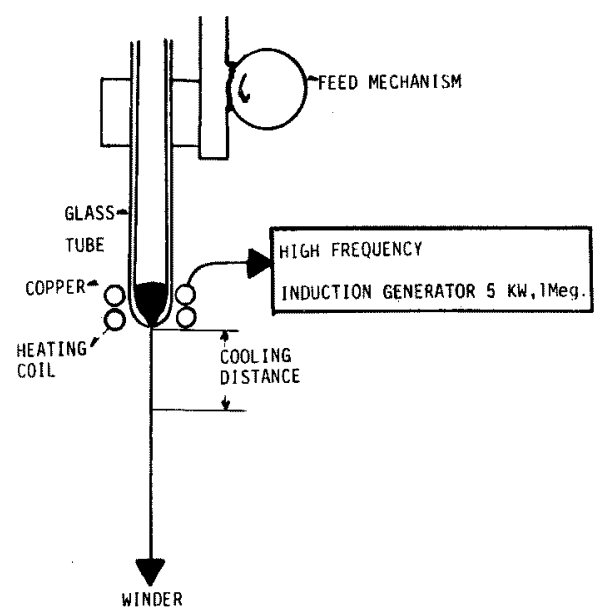

Fig. 1 Schematic drawing of an automatic micro-wire machine

化させて作製した試料を試料2とした。原材料として使用 した銅片は試薬 1 級の純度 $99.9 \%$ と試薬特級 $99.999 \%$ の 分析用銅片との 2 種類を用いたが以下に述べる諸物性はまっ たく同じであり，本㬰験においては市販試薬 1 級品を原材 料とした。溶解時に帯溶融精製効果が生じ紡絲した銅瀻維 の純度は原材料よりも高くなると考えられる。ガラス被覆 された銅繊維を $300 \mathrm{C} に$ 加熱した水酸化ナトリウム溶融 液中に $1 \mathrm{~min}$ 間漫漬して水洗し表面がラスを除去した。

以下の実験に使用した銅瀻稚の瀻維直径と製造条件を 表 1 に示す。䋐維直径は光学顕端鏡観察から求めた。

Table 1 Copper fiber made by the method of glass conjugated spinning

\begin{tabular}{c|c|c|c|c}
\hline $\begin{array}{c}\text { Sample } \\
\text { number }\end{array}$ & $\begin{array}{l}\text { Winding } \\
\text { speed } \\
(\mathrm{m} / \mathrm{min})\end{array}$ & $\begin{array}{c}\text { Cooling } \\
\text { distance* } \\
(\mathrm{cm})\end{array}$ & $\begin{array}{c}\text { Diameter } \\
(\mu)\end{array}$ & $\begin{array}{c}\text { Orientation at } \\
(200) \text { plane (\%) }\end{array}$ \\
\hline $1-1$ & 137 & 0 & 13.2 & 86.2 \\
$1-2$ & 137 & 2 & 9.6 & 90.5 \\
$1-3$ & 137 & 4 & 6.7 & 90.1 \\
$1-4$ & 137 & 6 & 6.0 & 91.7 \\
$2-1$ & 137 & - & 2.8 & 92.4 \\
$2-2$ & 108 & - & 5.8 & 92.0 \\
$2-3$ & 73.2 & - & 8.5 & 91.8 \\
$2-4$ & 50 & - & 10.0 & 92.2 \\
\hline
\end{tabular}

* see in Fig. 1.

前報で紡系銅瀻維は瀻雄軸に対してく100>に優先方 位を持つことが示された。

\section{2 熱処理}

各試料の熱処理を次のように行なった。銅䋐維を窒素 ガス.中昇温速度 $20^{\circ} \mathrm{C} / \mathrm{min}$ で $370^{\circ} \mathrm{C}$ まで上界させ，この 温度で $5 \mathrm{~min}$ 間保持し, 室温まで佮却した。

\section{3 示差走査熱量計（以下DSCと略記する）に 上る熱測定}

理学電機製示差走查熱量計 DSC 8085 型で試料約 10 $\mathrm{mg}$ を堂素ガス中, $2.5^{\circ} \mathrm{C} / \mathrm{min}, 5^{\circ} \mathrm{C} / \mathrm{min}, 10^{\circ} \mathrm{C} / \mathrm{min}$ $20^{\circ} \mathrm{C} / \mathrm{min}$ 加熱速度で室温から $450^{\circ} \mathrm{C}$ まで加熱し熱容 量の変化量を測定した。 5 回の平均値を実験值とした。

\section{4 引張試験}

東洋ボールドウイン製Model UTM-II 型テンシロン 引張試験機で試料長 $10 \mathrm{~mm}$, 引張り速度 $2 \mathrm{~mm} / \mathrm{min}$, 最 大荷重 $10 \mathrm{~g}$ で 20 本以上の引張り試験を行ないその平均 值から引張り強さと伸びを求めた。

\section{3、実験結果および考察}

\section{1 銅緎維の熱分析}

著者らはさきに空気中でDSCを用いて銅瀻維の熱分

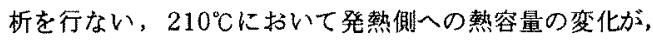
$306^{\circ} \mathrm{C}$ から吸熱僋人の熱容量の変化が観察されたことを 報告したが，空気中では銅㵶維が酸化し，正確な熱的 举動を表わしていない。正確な熱分析を行ならため, 窒 素がス中酸化のおきない条件のもとで銅瀻維を室温から $450 \mathrm{C}$ 範囲で $2.5 \mathrm{C} / \mathrm{min}, 5 \mathrm{C} / \mathrm{min}, 10 \mathrm{C} / \mathrm{min}, 20^{\circ} \mathrm{C} /$ $\min$ の各昇温速度で加熱して熱容量の変化量を測定した。

各算温速度で測定した試料 2-10熱分析曲線を図 2 に示す。図に拈いて $300^{\circ} \mathrm{C}$ 附近に発熱側への熱容量の変 化がみられる。变化開始温度 $T_{t}$ を図のように決め，熱量 变化速度の变化量をジャンプ値 $\Delta J$ とする。T

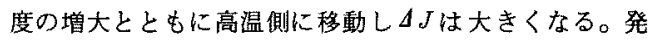
熱側への変化を示した試料を冷却し，再度熱分析を行な

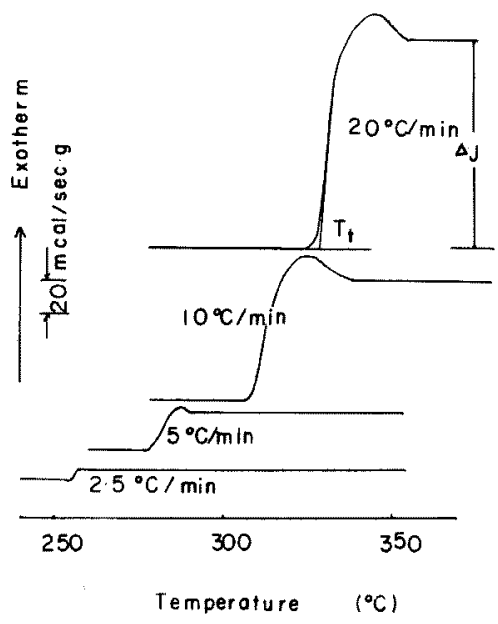

Fig. 2 Differential scanning calorimetric curve of copper fiber Sample 2-1 
った結果は $250^{\circ} \mathrm{C} ー 350^{\circ} \mathrm{C} に$ け拈け発熱側への変化はみ られずこの変化は 1 回の加熱で終了していることを示し ている。

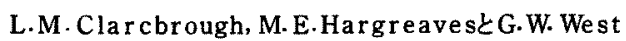
は引挍き加エした 99.98\%の純銅の熱量測定で $250^{\circ} \mathrm{C} \sim$

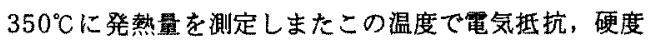
の急激な減少を観察し，この加工によって生じた眝蔵ェ ネルキの開放は再結晶に対伈しエネルギはびずみの一次 関数となることを報告している。そしてこれは变形によ って增大した転位の消隇によるものと結論している”。 ガラス併用溶融紡糸した銅樴維の熱測定に扔いて観察 される発熱変化む紡系時に生成した冷間加工組織の解消 によるむのと考えられる。

金属の加工組織の回復に対する熱測定の詳細な研究は 古くからなされている゙が微量の試料で比較的簓単に測 定できるDSCを適用させてガラス併用溶融紡系した銅 織維の熱分析を高分子のガラス転移と同様な解析の方法 ${ }^{83}$ で検討した。

冷間加エした銅の高温での回復または再結晶は加工に よって導入された転位の再配列や消滅が重要な因子とな り，再結晶化等ェネルキのの解放の模様は相当複雑である $か^{(6,7)}$ この過程が生じる速度は加工によって道入された 欠陥の濃度に比例し，その速度定数は温度によってアル レニゥス型の変化をすると仮定すると, 近似的に

$$
\ln \left(\phi / T_{t}\right)=C-E / R T_{t}
$$

となる。ここで 活性化エネルギ，Rは気体定数，Cは定数である。 $\ln$ $\left(\phi / T_{t}\right)$ と $1 / T_{t}$ と㥀線関係を示し, その㑯きからE が算出される。

冷却効果を变えて紡禾した銅䋐維の熱分析から求めた $\phi$ と $T_{t}$ を使って $\ln \left(\phi / T_{t}\right)$ と $1 / T_{t}$ との関係を図 $3 に$ 示寸。また，巻取速度を変えて紡系した銅䄉維に適用し た結果を図 4 に示す。全試料に扔いて $\ln \left(\phi / T_{t}\right)$ と $1 /$ $T_{t}$ はほぼ直線となり傾きから活性化エネルギを求めると 表 2 のよになる。

各試料間による活性化エネルギの差はほとんどなく約 $14.0 \mathrm{kcal} / \mathrm{mol}$ となる。寒測值に比較するといちじる しく小さい。

紡来銅絒維の熱分析で得られた発熱溉への熱容量の変 化は加工によって䢙入された欠陥の移動によって現われ たものでガラス併用溶融紡系法で製造した銅絨維にも引 抜き加工と同様に冷間加工によるびずみェネルギが生じ ている。

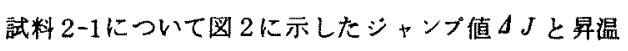
速度 $\phi$ との関保を図 5 に示す。昇温速度とともに熱容量 の变化はほぼ直線的に増加する。前述の变化開始温度の

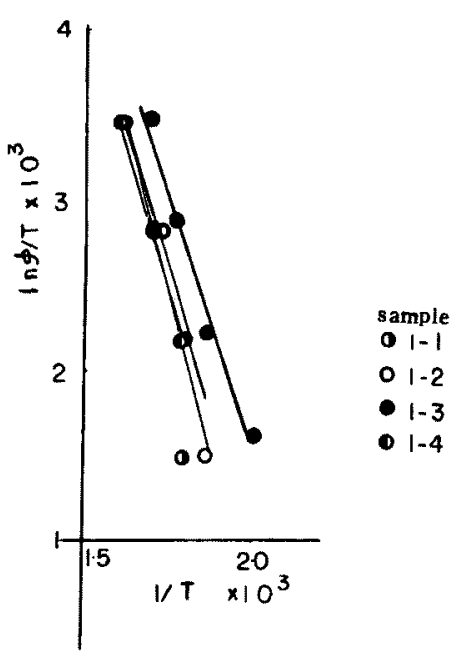

Fig. 3 Relation between $\ln (\phi / T)$ and $l / T$ Sample 1

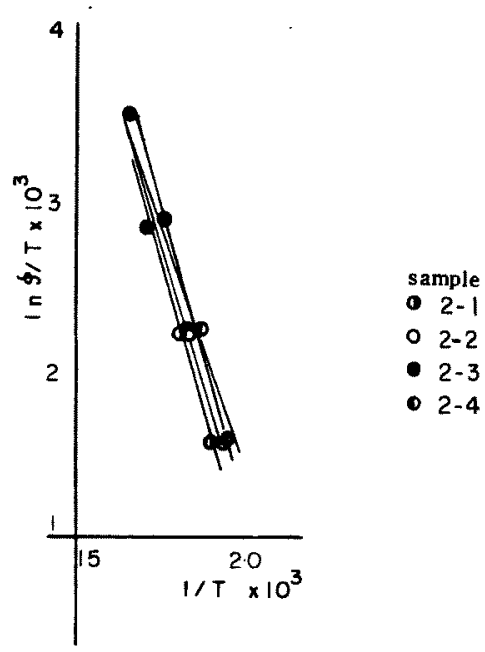

Fig. 4 Relation between $\ln (\phi / T)$ and $l / T$ Sample 2

Table 2 Apparent activation energy resulted from the plot of $\ln \left(\phi / T_{\mathrm{t}}\right)$ versus $l / T_{\mathrm{t}}$

\begin{tabular}{c|c|c|c}
\hline $\begin{array}{c}\text { Sample } \\
\text { number }\end{array}$ & $\begin{array}{l}\text { Activation } \\
\text { energy } \\
\text { (Kcal/mol) }\end{array}$ & $\begin{array}{c}\text { Sample } \\
\text { number }\end{array}$ & $\begin{array}{c}\text { Activation energy } \\
\text { (Kcal/mol) }\end{array}$ \\
\hline $1-1$ & 13.6 & $2-1$ & 14.8 \\
$1-2$ & 14.8 & $2-2$ & 14.6 \\
$1-3$ & 13.2 & $2-3$ & 13.6 \\
$1-4$ & 14.0 & $2-4$ & 14.8 \\
\hline
\end{tabular}




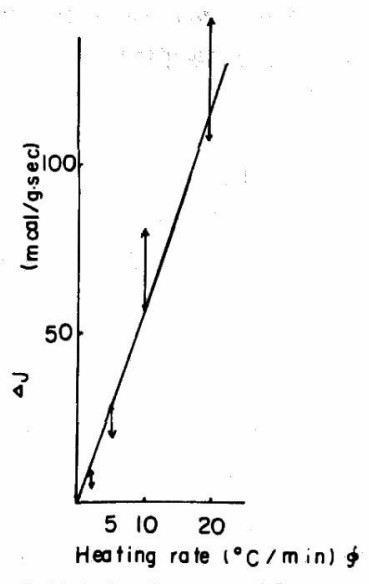

Fig. 5 Relation between $\Delta J$ as represented in Fig. 2 and heating rate $\phi$ Sample 2-1

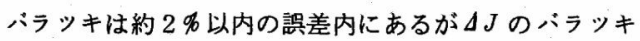
はそれに比較してたいんん大きく，そのバラッキを図 5 に矢印で図示する。これは測定中の試料のつめ方, 完全 にはDSCの原理を実現されえない装置上の問題 ${ }^{9)}$ を含 んでいるためであることなどによるものである。

冷却効果の異なる試料に対する $\Delta J$ と $\phi$ との関係を図 6 に示す。図中 1 は試料 1-1, 2 は試料 1-2, 3 は試料 1 -3，1-4である。測定値のバラッキはあるが冷却効果の 小さい試料のほうが昇温速度の依存性は大きくなる傾向 にある。

3.2 熱処理前後の銅緎維のX線回折写真の変化 試料 2-1 の紡系のまま $370^{\circ} \mathrm{C}, 5 \mathrm{~min}$ 間熱処理前後の X 線回折写真を図 7 に示す。写真はフィルム一試料間距離 約 $3 \mathrm{~cm}, \mathrm{CuK}_{\alpha}$ を線源として透過法で写したものである。 このピンホール写真の模式図を同図に示す。模式図に示 すように $\alpha$ を測定し, $\cos \rho=\cos \theta \cdot \cos \alpha$ の関係を用 いて $\rho$ を求めると(111)における

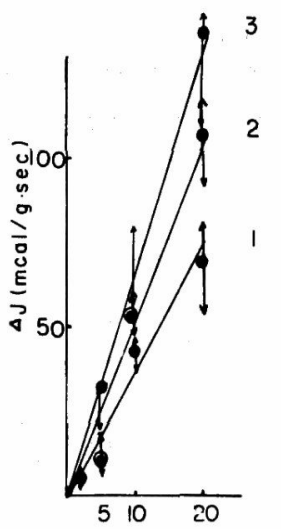

Heating rate $\left({ }^{\circ} \mathrm{C} / \mathrm{min}\right) \phi$

Fig. 6 Relation between $\Delta J$ as represented in Fig. 2 and heating rate $\phi$ 1... Sample 1-1, 2... Sample 1-2, 3... Sample 1-3, 1-4

では $90^{\circ}$ である。ここで $\theta$ はブラック角， $\alpha$ は図 7 に示 される角度でのは面間角である。 $<100>$ と $<100>$ の ○は $90^{\circ}$ であり $\langle 100\rangle$ と< 111$\rangle$ との面間角は $54.7^{\circ}$ である。

さらにディフラクト・メーター法によって熱処理前後 の構造を調べた。CuK $\alpha$ を線源として入射光線に垂直に 緎維を並べた時の結晶 (200)面のブラッグ角 $\theta$ を表 3 に 示す。

熱処理前のブラッグ角 $\theta$ は銅の格子定数から算出した (200) 面の $2 \theta=50.5^{\circ}$ よりも少し垔んでいる。特に冷 却位置を $2 \mathrm{~cm}, 4 \mathrm{~cm}$ の所で水水を噴水した場合に低角 側への歪みが観察される。定量的には詳細な補正項を考 えなければならないが ${ }^{10)}$ が定性的にはブラッグ角の低角 例への移動は格子定数が大きくなっていると考えられる。 これは紡系時に周囲を急冷することによって金属の冷却 速度が大きくなることと, 周囲のガラスが凝固しガラス の剪断力が增すことが考えられる。冷却速度が大きくな

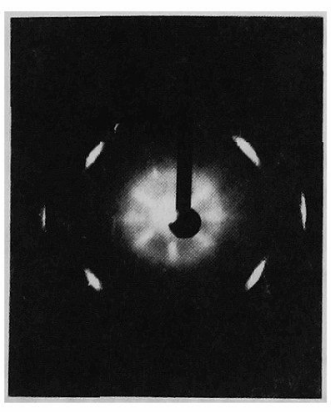

$7-1 \quad$ as spinning

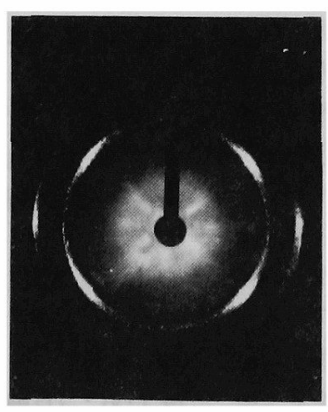

$7-2$ as heated at $370^{\circ} \mathrm{C}$ for $5 \mathrm{~min}$

Fig. $7 \quad \mathrm{X}$-ray diffraction photograph

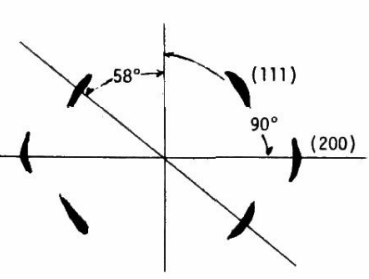

7-3 schematic drawing 
Table 3 The change of Bragg angle of (200) plane of copper fiber on heating at $370^{\circ} \mathrm{C}$ for $5 \mathrm{~min}$.

\begin{tabular}{c|c|c}
\hline Sample number & $\begin{array}{c}\text { as drawn } \\
2 \theta\left({ }^{\circ}\right)\end{array}$ & $\begin{array}{c}\text { heat treatment } \\
2 \theta\left({ }^{\circ}\right)\end{array}$ \\
\hline $1-1$ & 50.4 & 50.5 \\
$1-2$ & 49.6 & 50.5 \\
$1-3$ & 50.2 & 50.5 \\
$1-4$ & 50.4 & 50.5 \\
$2-1$ & 50.4 & 50.5 \\
$2-2$ & 50.5 & 50.5 \\
$2-3$ & 50.4 & 50.5 \\
$2-4$ & 50.5 & 50.5 \\
\hline
\end{tabular}

ると金属の液体状態により近い權造をとるため格子定数 は固体で安定な格子定数よりむ大きくなり，ガラス紊断 カが増せば引っぱりにより結晶の横方向の取樎が考えら れ，この二つが複雑に作用し合い，ちようど冷却位䈯が $2 \mathrm{~cm}$ くらいの所で昰みが最大となると考えられる。こ れらは熱処理により，より安定な格子定数へと移り 50.5 に近づく。

また織維軸方向の（100）面の配向度は熱処理前後に 差はみられなかった。

試料 2-1の銅瀻維の引張り試験を試料長 $10 \mathrm{~mm}$, 引張 り速度 $2 \mathrm{~mm} / \mathrm{min}$ で行なった結果，処理前にお゙いては 引张り強さは $130 \mathrm{~kg} / \mathrm{mm}^{2}$, 伸びは $2.2 \%$ であったが処 理後においては $70 \mathrm{~kg} / \mathrm{mm}^{2}, 3.2 \%$ となり，熱処理によ って引張り留さは低下し伸びは増加した。C.Grandは 線引き銅線について抗張力が $42 \mathrm{~kg} / \mathrm{mm}^{2}$ から $26 \mathrm{~kg} /$ $\mathrm{mm}$ に低下し，伸びが2务か $40 \%$ 変化すると報告し ている が溶融紡系した銅織維においても引抜加工と同 様な加工硬化が存在する。ここで銅織維の場合引張り菭 さが大きいのは前報”で示したように䄉維の直径が10\% 以下になると直径の减少とともに引張り強さが堌し、試

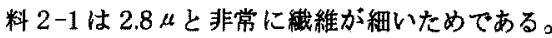

付記：本研究は昭和 48 年度文部省科学研究助成金に よるもので本誌をもって深謝する。

$$
\text { 文献 }
$$

1）長野正満，結城康夫，後藤共子，井山隆一; 緟学 誌., 29，T-461 (1973)

2) A. ギニェ, “ $X$ 線結晶学の理論と寒際”，386 (1967) 理学電機株式会社

3) L.K. Jetters, C. J.Mchargue, R.O. Willians ; J.Appl.phys., 27, 368(1956)

4) A.Freda, B.D.Cullity; Trans, $A I M E, 215$, 530(1959)

5) 仁田勇, “X 線結畾学”上, p. 600(1959) 丸 善株式会社

6) L.M.Clarebrough, M. E.Hargreaves; G. M. Wet t;Proc.Roy. Soc, A-232, 252 (1955)

7）日本金属学会，“新版転位諭一その金属学への応 用一”，244，281(1971) 丸盖株式会社

8) J.M. Barton;Polymer, 10, 151(1969)

9）高分子学会，“高分子相定法一構造と物性上” 142, 181(1973)

10) 仁田 勇，“X線結晶学”下，p.69(1959)丸善 株式会社

11) C.Grand;Rev.Met., 6, 1109(1909) 